\title{
An Empirical Analysis of Wine Tourists' Perspective on Tourism Infrastructure in Wine Regions of Maharashtra
}

\author{
Anupama Kotur Kaddi * and Paramita Suklabaidya ${ }^{\dagger}$
}

Abstract

Wine tourism in Maharashtra is slowly but surely evolving and entering into the 'growth phase'. Tourism infrastructure development is one of the primary steps in tourism product development process; therefore there is a need to assess the quality of existing tourism infrastructure in the wine tourism regions in Maharashtra so as to promote and further the growth of the wine tourism product in Maharashtra. It is important to understand the exact nature or type as well as importance of tourism infrastructure from the wine tourists' perspective for an enhanced and overall wine tourism experience. This paper is based on a study undertaken with two objectives:(a) to study the importance of various tourism infrastructure facilities in wine tourism growth; (b) to analyse the gap, if any, between the expected and the actual quality of critical tourism infrastructure in wine regions in Maharashtra as perceived by the tourists. For the purpose of this study, twelve (12) most critical tourism infrastructure facilities were identified and

* Research Scholar, School of Tourism and Hospitality Services Management, IGNOU; anukotur@gmail.com

† Assistant Professor, School of Tourism and Hospitality Services Management, IGNOU, Delhi; paramitaz@ignou.ac.in 
questionnaire was prepared on the same. The respondents to the questionnaire are the wine tourists as this paper aims to understand the perception of the wine tourists on tourism infrastructure facilities at the wine tourism destinations in the state. This paper is aimed at forming the basis for further research on wine tourism management in Maharashtra.

The paper will try to suggest a roadmap for 'need based infrastructure development' for a sustainable growth of the wine tourism destinations in Maharashtra based on the findings of the study.

Keywords: Wine Tourism, Tourism Infrastructure Facilities, Infrastructure Gap, Road Map

\section{Introduction}

Tourism infrastructure facilities are vital elements that propel a tourism destination's growth further as it is one of the primary steps in the tourism product development process. 'The competitiveness of these facilities at a national or international scale determines whether they become valuable assets for or likely impediments to, attracting visitors to a destination' (Warneken, 2002). The competitiveness of tourism destination is established not just by its attractions but also by the supporting infrastructure facilities, so much so that the very viability of promoting a tourist attraction depends on it. Lone, Rather \& Jain (2013) opined that the 'infrastructure development holds the key to sustained growth in the tourism sector'. The attractions of a destination can pull a tourist; but for sustainable growth it is important that supporting infrastructural facilities are available to meet and satisfy the expectations of the tourists; as discussed in the literature review given below. This research paper, a part of an ongoing research on wine tourism in India with special reference to Maharashtra, attempts to present an analysis of the perception of the wine tourists on tourism infrastructure facilities available at the wine tourism destinations in the state of Maharashtra. This study is aimed at forming the basis for further research on wine tourism 24 
management in Maharashtra and also contributing to research literature in wine tourism in India.

\section{Literature Review}

The literature review was taken up to understand the role and connection between infrastructural facilities and wine tourism as well as present scenario with respect to Wine Tourism in Maharashtra

\section{Wine Tourism and Infrastructure Facilities}

Getz (2000), described wine tourism as any 'travel related to the appeal of wineries and wine country, a form of niche marketing and destination development and an opportunity for direct sales and marketing on the part of the wine industry' (as cited in Adams, 2006). Wine tourism as described by the South Australian Tourism Commission (1997) is 'any experience relating to wineries or wine production in which visitors participate when on a day trip or longer visit. Wine tourism can range from a visit to a single cellar door outlet while en route to a main holiday destination, to an intensive week long, live-in experience focused on the wine process'(as cited in Kirkman, 2010). Wine tourism is essentially a combination and correlation between two important industries Tourism and Wine. Both these industries, for the purpose of wine tourism, contribute to one another's' growth. For tourism, it is yet another interest, yet another attraction and newer tourist experiences. For the wine industry, it is alternate form of revenue, opportunity for cellar-door sales and brand promotion. Sharma (2005), further aptly summarized wine tourism as simultaneously being, a form of consumer behaviour; a strategy by which destinations develop and market wine-related attractions and imagery; and a marketing opportunity for wineries to educate, and to sell their products directly to consumers.

For wine tourism, the key attractions are the wine making processes and wine knowledge. Wine industry which is an elemental attraction for wine tourism must also be combined with other elements from tourism industry for a complete wine tourism 
experience. 'While tourist attractions form a powerful component of the supply side of tourism-enticing, luring and stimulating interest in travel - they are only one component of the necessary tourism infrastructure. Investment in supporting businesses (e.g., hotels, transportation companies), soft infrastructure (e.g., local community colleges, universities, and trade and professional associations) and hard infrastructure (e.g., roads, airports, marinas, water and sewer lines, and telecommunications) is the key to developing a successful tourism destination. Their interdependence dictates a need for a strategic wide-angle approach to tourism infrastructure development' (Ontario Ministry of Tourism Report, 2009).

Further, Kennedy and Forman introduced the concept of Knowledge infrastructure and its importance in the success of a tourism destination. They opined that "investment in 'knowledge infrastructure' will be critical for regional areas' success in the new economy" (Kennedy and Forman, 2003) (as cited in Gammack, 2006). 'A knowledge economy involves infrastructure factors including industry clusters and other inter-organizational linkages, effective use of information and communication technologies (ICTs), and linkages between education, business, community and government. Increasing the external focus of regions through leveraging greater connectedness, sharing best practice for organizational and community learning, relevant, rapid innovation and research dissemination and knowledge sharing are all indicated' (Gammack, 2006). Hence, the growth of a wine tourism region does not only depend on the tourist attractions it has to offer but also on the existence and quality of other tourism infrastructure facilities. 'Getz (1998) also argues that attributes of a wine region, such as the scenery and open spaces, also provide an incentive to visit the region. It has been argued (Beames, 2003) that an important challenge facing regions is to be able to create a total experience for tourists rather than merely the opening of cellar doors, thus, a deeper understanding of the consumer is required' (as cited in Roberts \& Sparks, 2006). This presents an area of study to understand the level and quality of tourism infrastructure in the 26 
wine regions as perceived and experienced by the wine tourists to the state of Maharashtra.

\section{Wine Industry and Wine Tourism in Maharashtra}

A matured wine industry is but imperative to the growth and development of wine tourism. Any study on wine tourism in Maharashtra cannot be undertaken in isolation, without understanding wine industry in the state. The state of Maharashtra saw the establishment of India's first international standard winery in the early 1980's in Narayangaon near Pune. Five more were established and functional by the year 2000. The decade that followed can be considered significant for Indian wine industry as over 60 wineries came into being. Nashik, Pune, Sangli, Solapur and Osmanabad are important wine regions in Maharashtra. The current statistics by Indian Grape Processing Board (IGBP) 'indicate that there are as many as 72 wineries. However, a third or more of these wineries are not producing or are producing below capacity. Some wineries have abandoned their brands and are selling grape juice to larger wineries for further processing' (Sood, 2012). As per a report by Dr. Hande (2013), in Maharashtra, total area under grape cultivation is 7000 acres with annual production of 15 Lakh Metric Tons of grapes. 'The industry, which was barely 150,000200,000 cases (of wines) strong at the turn of the millennium, was growing at the rate of $25-30 \%$ for the five years prior to the downfall in 2008; it reached a peak of $1.5 \mathrm{~m}$ cases, including about 250,000 cases of imported wines. The years 2008 to 2011 saw a slide in the domestic wine production and consumption, though the market flirted with a peak in April to March 2011 to 2012, and a growth of $20 \%$ to $25 \%$ is expected to continue over the next five years' (sic) (Arora, 2013). 'The total investment on wineries in Maharashtra was Rs. $431.71 \mathrm{Cr}$ in 2009 and rose to Rs. $452.10 \mathrm{Cr}$ in 2012' (Hande, 2013).

Wine Tourism in Maharashtra has moved from being in a nascent stage to growth stage akin to its parent industry - wine industry. Wine tourism, as an activity within the wine industry's framework, pre-necessitates existence of several facilities to cater to wine tourists, as mentioned above. Wineries in Maharashtra, having 
realised the benefits of wine tourism inclusion into mainstream winery operations, are now open to venturing into wine tourism. Nashik district of Maharashtra, being the most important wine region in Maharashtra, has become the primary location for all the wine tourism initiatives in the state. While Nashik has emerged as the hub of wine tourism activities in the state with some of the most important vineyards located there such as Sula, York, ZampaGrover, Vallonne, Reveilo and Charosa; Pune too is competing with its wineries located nearby such as Four Seasons and Fratelli. Other important districts of Sholapur and Sangli hold fair potential to be promoted as wine tourism regions.

\section{Research Objectives}

The study was undertaken in order to meet the below listed objectives:

a) To study the importance of various tourism infrastructure facilities for the growth of wine tourism;

b) To analyse the gap, if any, between the expected quality and the actual quality of critical tourism infrastructure in wine regions of Maharashtra, as perceived by the wine tourists.

\section{Research Methodology}

The data for the purpose of the study were collected from a combination of both primary and secondary sources. While for the first objectives the data was primarily based on the secondary sources, for the latter, primary data collection was undertaken using structured questionnaires. The survey questionnaire was constructed after reviewing various research works undertaken in wine tourism, tourism infrastructure gap studies and other allied areas. Some of the notable research works referred to were by Alonso (2005), Ministry of Tourism, India (2010) and Kirkman (2010). Twelve (12) critical tourism infrastructure facilities were identified and the respondents (wine tourists) were asked to rank them under two heads namely, (i) the importance attached by them to the tourism infrastructure facilities; and (ii) the actual level and 28 
quality of the existing tourism infrastructure facilities. For both the sections Likert scales were used. While the former indicated ranking from 1 to 5 (1=Irrelevant to $5=$ Very Important 3 being the mid-point indicating Neutral), the latter indicated ranking from 1 to 5 (1=Poor to $5=$ Excellent 3 being the mid-point indicating Average). Sampling method adopted was purposive sampling. Primary data collection was undertaken by the authors through self-administered surveys at Nashik and wine festivals in Mumbai and Pune. Questionnaires were also circulated through Facebook and Emails. A total of 483 responses were received and the scrutiny of the same showed useable responses to be 390 only. Both the sections under which the ranking were undertaken namely, (i) the importance attached or expected level of range and quality of tourism infrastructure facilities; and (ii) the actual level of range and quality of the existing tourism infrastructure facilities were tested for Internal Consistency using Cronbach's Alpha and the results indicated a good internal consistency with alpha values of a $=.706$ and $\alpha=.799$ respectively.

\section{Data Analysis}

\section{a) Demographic Profile of the Respondents}

A total of 390 usable responses were used in the study of which $53.6 \%$ were male respondents and $46.4 \%$ were female respondents. As many as $36.9 \%$ of the responses were received from the age group of $26-35$ years and $32.3 \%$ of the responses were received from the age group of $36-45$ years. It is interesting to note that $55.4 \%$ of the wine tourists that participated in the survey were with an educational qualification of Post Graduate and above. Among the respondents $44.6 \%$ and $35.4 \%$ were Employed and Self Employed respectively. This trend shows that senior citizens are not yet an important segment for this type of tourism. The table below lists a detailed demographic profile of the wine tourists i.e. respondents. It is interesting trend that women are emerging as an important segment for wine tourism, since $46.4 \%$ of the responses among the wine tourists were received from women. 
Table 1: Demographic Profile of the Respondents

\begin{tabular}{|c|c|c|c|}
\hline \multicolumn{2}{|c|}{ Variables } & Frequencies & Percentage (\%) \\
\hline \multirow{3}{*}{$\begin{array}{c}\text { Number } \\
\text { of Respondents }\end{array}$} & Male & 209 & $53.6 \%$ \\
\hline & Female & 181 & $46.4 \%$ \\
\hline & Total & 390 & $100 \%$ \\
\hline \multirow{5}{*}{$\begin{array}{c}\text { Age Group of } \\
\text { the } \\
\text { Respondents }\end{array}$} & 18 to 25 years & 60 & $15.4 \%$ \\
\hline & 26 to 35 years & 144 & $36.9 \%$ \\
\hline & 36 to 45 years & 126 & $32.3 \%$ \\
\hline & 45 to 60 years & 48 & $12.3 \%$ \\
\hline & 60 and above & 12 & $3.1 \%$ \\
\hline \multirow{4}{*}{$\begin{array}{c}\text { Educational } \\
\text { Qualification }\end{array}$} & Undergraduate & 24 & $6.2 \%$ \\
\hline & Professional Courses & 30 & $7.7 \%$ \\
\hline & Graduate & 120 & $30.8 \%$ \\
\hline & $\begin{array}{l}\text { Post Graduate } \\
\text { and Above }\end{array}$ & 216 & $55.4 \%$ \\
\hline \multirow{6}{*}{ Profession } & Employed & 174 & $44.6 \%$ \\
\hline & Self Employed & 138 & $35.4 \%$ \\
\hline & Housewife & 18 & $4.6 \%$ \\
\hline & Retired & 18 & $4.6 \%$ \\
\hline & Student & 36 & $9.2 \%$ \\
\hline & Others & 6 & $1.5 \%$ \\
\hline
\end{tabular}

\section{b) Expected Level and Quality of Infrastructure for Wine Tourism as Perceived by Wine Tourists}

Infrastructure for wine tourism was studied under two sections viz., wine tourism infrastructure available within the wineries and vineyards and the supporting infrastructure facilities in the wine tourism region. For the purpose of this research paper, only the supporting infrastructure facilities present in the wine tourism region were taken into consideration. The respondents were, in the first section of the questionnaire, asked to rank 12 listed Infrastructure and Superstructure Facilities under the head 'How important is it to you' to determine the expected quality and level of importance that the wine tourists attached to each of the 12 listed facilities. Likert scale indicating importance on a scale of 1 to 5 (1=Irrelevant, 2=Not Important, 3=Neutral, 4=Important and $5=$ Very Important) were used where the respondents ranked them 30 
based on the importance they attached to each of the listed facilities, i.e. their expectation. The Mean scores of the results are illustrated in the table below:

Table 2: Mean scores of tourists' opinion on expected level of tourism infrastructure in wine regions

\begin{tabular}{|c|c|c|c|}
\hline Tourism Infrastructure Facilities & Mean & Median & $\begin{array}{c}\text { Std. } \\
\text { Deviation }\end{array}$ \\
\hline $\begin{array}{l}\text { a. Connectivity to the Vineyard/ } \\
\text { Winery }\end{array}$ & 4.45 & 5.00 & .725 \\
\hline $\begin{array}{l}\text { b. Quality of Roads leading to the } \\
\text { Vineyards }\end{array}$ & 4.35 & 5.00 & .774 \\
\hline c. Signage \& Directions on the Road & 4.49 & 5.00 & .683 \\
\hline $\begin{array}{l}\text { d. Public Transport Services to the } \\
\text { Wine Region }\end{array}$ & 3.89 & 4.00 & 1.026 \\
\hline $\begin{array}{l}\text { e. Parking Facilities at the } \\
\text { Destination }\end{array}$ & 4.26 & 4.00 & .934 \\
\hline $\begin{array}{l}\text { f. Availability of Tour Operators for } \\
\text { Wine Tours }\end{array}$ & 3.92 & 4.00 & 1.115 \\
\hline $\begin{array}{l}\text { g. Restaurants and other catering } \\
\text { facilities }\end{array}$ & 4.38 & 4.00 & .673 \\
\hline h. Wayside amenities & 3.68 & 4.00 & .980 \\
\hline $\begin{array}{l}\text { i. Availability of Accommodation } \\
\text { facilities }\end{array}$ & 3.86 & 4.00 & .960 \\
\hline j. Shopping Facilities & 2.85 & 3.00 & 1.100 \\
\hline $\begin{array}{l}\text { k. Other attractions besides wineries } \\
\text { / vineyards }\end{array}$ & 3.25 & 3.00 & 1.242 \\
\hline $\begin{array}{l}\text { 1. MTDC 'May I Help You' Centres } \\
\text { at the Destination }\end{array}$ & 3.77 & 4.00 & 1.135 \\
\hline
\end{tabular}

The Mean score results indicate that wine tourists perceived Connectivity to Vineyards, Quality of Roads, Signage and Direction as very important part of the tourism infrastructure in the wine regions. Further, proper parking facilities and catering facilities such as restaurants were also ranked between 'important' and 'very important' by the wine tourists. While the former facilities indicate an importance perceived for accessibility factor for tourism destinations, the latter indicate that other amenities are of equal 
importance to the development of a tourism destination. Other remaining factors - Public transport services, Availability of tour operators, Accommodation facility and visitor centres by MTDC were seen as moderately important while shopping facilities were seen as not important for wine tourists as indicated by a low Mean score. In this paper, the level of importance, with regard to a particular infrastructure facility, as perceived by the tourists is being considered as the expectation of the respondents.

\section{c) Actual Level and Quality of Infrastructure for Wine Tourism as Experienced by Wine Tourists}

The data above gives an understanding of the importance wine tourists attaches to the presence of the various tourism infrastructure facilities at wine tourism regions. This study though intended to probe further, in order to understand if wine tourists perceived the existing tourism infrastructure facilities at par with their expected level. In order to study the same the respondents were, in the second section of the questionnaire, asked to rank the same 12 listed Infrastructure and Superstructure Facilities under the head 'Your Rating on the Present Condition'. Likert scale indicating importance on a scale of 1 to 5 (1=Poor, 2=Not Good, $3=$ Neutral, 4=Good and 5=Excellent) were used where the respondents ranked them based on their experience about the quality of the tourism infrastructure and superstructure facilities present in the wine tourism regions. The mean scores of the results are illustrated in the table below:

Table 3: Mean scores of tourists' opinion on actual condition of tourism infrastructure in wine regions

\begin{tabular}{|l|c|c|c|}
\hline \multicolumn{1}{|c|}{ Tourism Infrastructure Facilities } & Mean & Median & $\begin{array}{c}\text { Std. } \\
\text { Deviation }\end{array}$ \\
\hline a. Connectivity to the Vineyard/ Winery & 3.22 & 3.00 & .986 \\
\hline $\begin{array}{l}\text { b. Quality of Roads leading to the } \\
\text { Vineyards }\end{array}$ & 2.78 & 3.00 & 1.185 \\
\hline c. Signage \& Directions on the Road & 3.02 & 3.00 & 1.001 \\
\hline $\begin{array}{l}\text { d. Public Transport Services to the Wine } \\
\text { Region }\end{array}$ & 2.03 & 2.00 & .977 \\
\hline e. Parking Facilities at the Destination & 4.05 & 4.00 & 1.089 \\
\hline
\end{tabular}




\begin{tabular}{|l|c|c|c|}
\hline \multicolumn{1}{|c|}{ Tourism Infrastructure Facilities } & Mean & Median & $\begin{array}{c}\text { Std. } \\
\text { Deviation }\end{array}$ \\
\hline $\begin{array}{l}\text { f. Availability of Tour Operators for Wine } \\
\text { Tours }\end{array}$ & 2.86 & 3.00 & 1.215 \\
\hline g. Restaurants and other catering facilities & 3.49 & 4.00 & 1.099 \\
\hline h. Wayside amenities & 2.62 & 3.00 & 1.035 \\
\hline i. Availability of Accommodation facilities & 3.12 & 3.00 & 1.032 \\
\hline j. Shopping Facilities & 2.45 & 3.00 & 1.179 \\
\hline $\begin{array}{l}\text { k. Other attractions besides wineries } \\
\text { /vineyards }\end{array}$ & 2.40 & 2.00 & 1.006 \\
\hline $\begin{array}{l}\text { l. MTDC 'May I Help You' Centres at the } \\
\text { Destination }\end{array}$ & 1.89 & 2.00 & .995 \\
\hline
\end{tabular}

The table above indicating the mean scores of ratings of wine tourists' perception of the actual condition of infrastructure facilities in wine tourism regions in Maharashtra show that wine tourists did not consider the accessibility factor to be favourable for wine tourism growth. The mean scores on 3.22, 2.78 and 3.02 belonging to road connectivity, quality of roads and signage and directions respectively indicate the responses mostly varied between 'neutral' to 'not good'. Wine tourists also considered public transport to the wine tourism regions and vineyards as 'not good'. While there is a good network of state run transport system to the cities near to the wine region, there lacks transport network to the wine region and within the wine region. Other important tourist amenities such as restaurants, way side amenities, shopping facilities also fared between 'neutral' to 'not good'. However, wine tourists expressed satisfaction towards the range and quality of parking and accommodation facilities. Nashik, the largest hub of wine tourism activities, has a range of hotels to choose from for the wine tourists while other cities such as Baramati, Sangli and Sholapur do not have many accommodation options. It was also observed that wine tourists ranked the involvement of MTDC in wine tourism between 'very bad' to 'poor' at a mean score of 1.89. This reflects the need for greater involvement of the state tourism development authority in wine tourism promotion. 


\section{d) Gap between the Expected and Actual Level and Quality of Infrastructure for Wine Tourism as Perceived by Wine Tourists}

A comparison table presented below indicates the differences in the mean values in the expected and the actual level in the range and quality of tourism infrastructure facilities available in the wine regions of Maharashtra. A high mean value in expected level assessment indicates a high level of importance attached and vice versa. Further, a high mean value in actual level assessment indicates tourists' satisfaction with the range and quality of tourism infrastructure in Maharashtra's wine regions and vice versa.

Table 4: Comparison table indicating mean values of expected level and actual level tourism infrastructure facilities in wine regions of Maharashtra

\begin{tabular}{|c|c|c|}
\hline \multirow[t]{2}{*}{ Tourism Infrastructure Facilities } & \multicolumn{2}{|c|}{$\begin{array}{l}\text { Mean Values of Tourists' Opinion } \\
\text { on Range and Quality of Tourism } \\
\text { Infrastructure in Wine Regions }\end{array}$} \\
\hline & Expected Level & Actual Level \\
\hline $\begin{array}{l}\text { a. Connectivity to the Vineyard/ } \\
\text { Winery }\end{array}$ & 4.45 & 3.22 \\
\hline $\begin{array}{l}\text { b. Quality of Roads leading to the } \\
\text { Vineyards }\end{array}$ & 4.35 & 2.78 \\
\hline c. Signage \& Directions on the Road & 4.49 & 3.02 \\
\hline $\begin{array}{l}\text { d. Public Transport Services to the } \\
\text { Wine Region }\end{array}$ & 3.89 & 2.03 \\
\hline $\begin{array}{l}\text { e. Parking Facilities at the } \\
\text { Destination }\end{array}$ & 4.26 & 4.05 \\
\hline $\begin{array}{l}\text { f. Availability of Tour Operators for } \\
\text { Wine Tours }\end{array}$ & 3.92 & 2.86 \\
\hline $\begin{array}{l}\text { g. Restaurants and other catering } \\
\text { facilities }\end{array}$ & 4.38 & 3.49 \\
\hline h. Wayside amenities & 3.68 & 2.62 \\
\hline $\begin{array}{l}\text { i. Availability of Accommodation } \\
\text { facilities }\end{array}$ & 3.86 & 3.12 \\
\hline j. Shopping Facilities & 2.85 & 2.45 \\
\hline $\begin{array}{l}\text { k. Other attractions besides wineries } \\
\text { / vineyards }\end{array}$ & 3.25 & 2.40 \\
\hline $\begin{array}{l}\text { 1. MTDC 'May I Help You' Centres at } \\
\text { the Destination }\end{array}$ & 3.77 & 1.89 \\
\hline
\end{tabular}


It may be observed that in all the tourism infrastructure facilities there is a difference between the mean values of tourists' opinion on range and quality of tourism infrastructure in wine regions. It is distinctly observable that the 'Expected Level of Range and Quality' of tourism infrastructure for all listed facilities is higher than that of the 'Actual level of Range and Quality' of tourism infrastructure. Where the gap is higher, for instance in the case of 'Quality of Roads leading to the Vineyards', 'Signage \& Directions on the Road', 'Public Transport Services to the Wine Region' and 'MTDC 'May I Help You' Centres at the Destination' it may be inferred that the gap between expected and actual levels is high indicating a dissatisfaction among wine tourists on account of those tourism infrastructure facilities in wine regions of Maharashtra. Further, where the gap is narrow, it may be inferred that those facilities are on par with the tourists' expected level of range and quality, for instance, 'Parking Facilities at the Destination', and 'Availability of Accommodation facilities'.

From the data analysis and discussion, it is evident that there exists a variance or gap between the expected and actual level of range and quality of tourism infrastructure facilities in the wine tourism regions of Maharashtra. In order to test the results for statistical significance, Chi square test was performed. Confidence level was determined at $95 \%$ with an alpha value of 0.05 . The null hypothesis was framed as under,

$H_{0}$ : There is no significant difference between the wine tourists opinion about expected and actual quality of tourism infrastructure.

The results of the chi square test along with statistical significance are illustrated in the table below: 
Table 5: Chi Square Test Results and Statistical Significance of the Results

\begin{tabular}{|l|l|c|}
\hline \multicolumn{1}{|c|}{$\begin{array}{c}\text { Tourism Infrastructure } \\
\text { Facilities }\end{array}$} & \multicolumn{1}{|c|}{ Chi Square Test Results } & $\begin{array}{c}\text { Statistical } \\
\text { Significance }\end{array}$ \\
\hline $\begin{array}{l}\text { a. } \text { Connectivity to the } \\
\text { Vineyard/ Winery }\end{array}$ & $X^{2}(9, \mathrm{~N}=390)=42.55, p=.00$ & Significant \\
\hline $\begin{array}{l}\text { b. Quality of Roads } \\
\text { leading to the Vineyards }\end{array}$ & $X^{2}(12, \mathrm{~N}=390)=53.82, p=.00$ & Significant \\
\hline $\begin{array}{l}\text { c. Signage \& Directions on } \\
\text { the Road }\end{array}$ & $\chi^{2}(12, \mathrm{~N}=390)=92.62, p=.00$ & Significant \\
\hline $\begin{array}{l}\text { d. Public Transport } \\
\text { Services to the Wine } \\
\text { Region }\end{array}$ & $X^{2}(16, \mathrm{~N}=390)=66.37, p=.00$ & Significant \\
\hline $\begin{array}{l}\text { e. Parking Facilities at the } \\
\text { Destination }\end{array}$ & $X^{2}(16, \mathrm{~N}=390)=212.82, p=.00$ & Significant \\
\hline $\begin{array}{l}\text { f. Availability of Tour } \\
\text { Operators for Wine Tours }\end{array}$ & $X^{2}(16, \mathrm{~N}=390)=104.62, p=.00$ & Significant \\
\hline $\begin{array}{l}\text { g. Restaurants and other } \\
\text { catering facilities }\end{array}$ & $X^{2}(8, \mathrm{~N}=390)=96.60, p=.00$ & Significant \\
\hline h. Wayside amenities & $\chi^{2}(16, \mathrm{~N}=390)=116.65, p=.00$ & Significant \\
\hline $\begin{array}{l}\text { i. Availability of } \\
\text { Accommodation facilities }\end{array}$ & $\chi^{2}(8, \mathrm{~N}=390)=147.78, \mathrm{p}=.00$ & Significant \\
\hline j. Shopping Facilities & $\chi^{2}(16, \mathrm{~N}=390)=181.67, \mathrm{p}=.00$ & Significant \\
\hline $\begin{array}{l}\text { k. Other attractions } \\
\text { besides wineries } \\
\text { /vineyards }\end{array}$ & $\chi^{2}(16, \mathrm{~N}=390)=196.77, p=.00$ & Significant \\
\hline $\begin{array}{l}\text { l. MTDC 'May I Help You' } \\
\text { Centres at the Destination }\end{array}$ & $X^{2}(12, \mathrm{~N}=390)=128.87, \mathrm{p}=.00$ & Significant \\
\hline
\end{tabular}

For all of the 12 factors the test was significant at $p<0.05$ providing sufficient evidence to reject the null hypothesis. Therefore, we infer that there exists a significant statistical difference between the wine tourists' opinion about the expected and actual level of range and quality of tourism infrastructure available at present in Maharashtra. 


\section{Conclusion and suggestions}

The literature review in the beginning of this research paper highlighted the importance of tourism infrastructure in the wine regions meeting the first objective of the research paper. Further, it can be inferred from the Tourism Infrastructure Gap analysis carried out through the Comparison table and the results of Chi Square Test that:

i. The wine tourists considered tourism infrastructure facilities as important;

ii. The wine tourists observed that the actual condition of the infrastructural facilities are not at par with their expected level of range and quality; and

iii. A Gap between Tourism Infrastructure Demand (Expected Level of Range and Quality) and Supply (Actual Level of Range and Quality) exists.

The above analysis meets the second objective of the research paper. The results, however, are of concern as the wine tourism sector is still in its growth stage and tourist satisfaction will play a big role in its further growth in the country and state. This brings up the question as to what are the measures that can be taken up to match the demand and supply of tourism infrastructure in wine regions of Maharashtra.

Tourism infrastructure in the wine regions of Maharashtra is of critical importance considering that wine tourism is moving into a growth phase. Growth phase, where tourist numbers are ever on the increase, the wine tourism service providers such as vineyards, wineries, hotels, F \& B establishments and travel trade have shown greater involvement to understand the demands of the wine tourists in order to tap this growing market. The above study has established a gap between Tourism Infrastructure Demand (Expected Level of Range and Quality) and Supply (Actual Level of Range and Quality). But, any infrastructure development for tourism requires an in-depth understanding of the market and a thorough planning before any development is undertaken. As 
Boers \& Cottrell (2005) observed "it is generally acknowledged that these 'unplanned' types of development are the ones most likely to be associated with low levels of visitor satisfaction and adverse impact on (tourism) resources". Suggested below is a roadmap to match the demand and supply of tourism infrastructure in the wine regions of Maharashtra based on the study results and field visits by the authors:

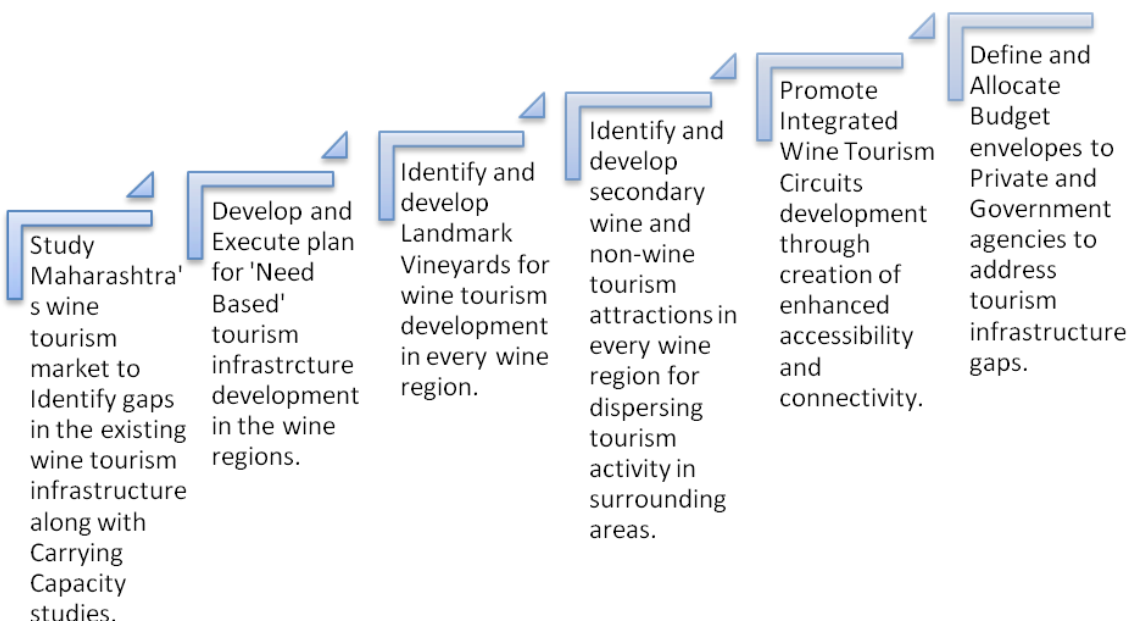

Illustration 1: Suggested Roadmap for Tourism Infrastructure Development Planning in Wine Tourism Regions in Maharashtra

Carrying Capacity Studies: One of the foremost steps in tourism infrastructure planning is to understand the tourism market by way of carrying capacity studies. With sustainable destination growth increasingly becoming need of the hour globally, any tourism infrastructure development in the wine regions of Maharashtra must be undertaken with due consideration to the impact studies and carrying capacity studies, to determine the optimum level of tourism activity and development that can be undertaken in the wine region without causing any negative impact on the destination. Carrying capacity studies must be undertaken to encompass various aspects of the wine region and may be undertaken in the below listed areas: 
a. Ecological Carrying Capacity Study: This study relates to determining the optimum number of tourists or the development that a destination can handle without leaving any adverse impact on the ecological environment of the destination i.e. Environmental Impact Assessment (EIA).

b. Social Carrying Capacity Study: The local and indigenous people are the focus of this study where the tourism development and tourist visitation in a destination should be of such level that it does not cause any harm to the social fabric of the destination.

c. Economic Carrying Capacity Study: Tourism development, no doubt brings economic benefits to the destination and the region at large, however, an optimum level of development must be pre-determined so as to not cause an imbalance in the local economy of the destination such as inflation, price rise etc.

d. Psychological Carrying Capacity Study: This study refers to the visitor satisfaction of tourists in a tourist destination or attraction. Level and quality of tourism services and facilities must be taken into consideration so as to not cause a decrease in the satisfaction levels of tourists.

Professional agencies may be appointed to carry out carrying capacity studies in order to determine the optimum level of development most suited to wine regions of Maharashtra before any development plan is executed.

Need-Based Tourism Infrastructure Development: Not all wine regions of Maharashtra are endowed with similar or equal tourism potentials. Therefore it is important to suit the infrastructure development needs based on the tourism potential that the destination presents by taking into consideration the below aspects:

a. Core tourism strengths of the wine region;

b. Destination Lifecycle Phase in which the destination is presently moving in;

c. Visitor expectations from the wine tourism region; 
Through adopting this approach of need based development wasteful expenditure and underutilisation of tourism infrastructure may be avoided to a great extend in the wine regions of Maharashtra.

Identify and Develop Landmark Vineyards: Identifying and developing 'Landmark Vineyards' in every wine region of Maharashtra is a necessary step to ensure a balanced growth of wine tourism in every wine region. Promotion of landmark vineyards in every wine region will not only help achieve diversification of wine tourism attractions in the state but also help attain equilibrium in developing tourism infrastructure base for every wine region. For instance, Sula may be considered as the landmark vineyard for Nashik's Sawargaon region and Fratelli Vineyard may be considered as a landmark vineyard for Baramati region. By promoting landmark vineyards in each wine region, smaller vineyards too are benefitted through increase in visitations. Diversifying wine tourism offering in the state in a great way offsets burden on tourism infrastructure of a single region of Maharashtra such as Nashik.

\section{Identify and Develop Secondary Attractions in Wine Regions:} Wine based tourism resources are elemental to wine tourism but then non-wine tourism resources are also equally important for the growth of wine tourism. A blend of cultural, gastronomic and nature-based tourism resources with wine tourism shall, in a great way, help dispersing tourism activity in surrounding areas thereby reducing the burden on landmark vineyards. For instance, Napa Valley in California, USA, today is not just a wine tourism hub but an art and cultural hub promoting several forms of art through a fine blending with wine culture. Such a development also promotes repeat visitation among tourists by diversifying wine tourism products and services. Distributing tourists in several pockets of the wine region also ensures lesser burden on a single pocket and its tourism infrastructure, resulting in a balance in the physical carrying capacity of the wine tourism destination.

Integrated Wine Tourism Circuits: Promotion of Integrated Wine Tourism Circuits through creation of enhanced accessibility and 40 
connectivity holds the key to sustainable tourism growth in the wine tourism regions of Maharashtra. Through creation of integrated tourism circuits a focussed development of tourism infrastructure takes place in these circuits. Integrated Wine Tourism Circuits enable creating 'Wine Tourism Hot-Spots' in Maharashtra where international standard tourism infrastructure development may be encouraged through public-private partnership. Some of the suggested 'Wine Tourism Hot-Spots' for Maharashtra can be:

a. Sula, Sawargaon Sub Region, Nashik Wine Region

b. Zampa-Grover, Igatpuri Sub Region, Nashik Wine Region

c. Fratelli, Baramati Wine Region

Defining and Allocation of Budgets: Any tourism infrastructure development pre-necessitates proper defining and allocation of budgets in order to address the infrastructure gaps in the region. Both Government and private bodies play an equally important role in implementing infrastructure development plans. Through public-private partnership, infrastructural development plans may be funded and realised.

The results of this study also need to be viewed in the light of its limitations such as the primary data was collected only from wine tourists and not from other stakeholders such as locals, travel agents or tour operators, and others. These limitations, based on the present findings are the foundation for further studies on carrying capacity, benchmarking studies and EIA studies for developing wine tourism in Maharashtra. However, there is a need for greater understanding among the stakeholders of wine industry in Maharashtra regarding the importance of academic research in this field; and thus soliciting and providing greater cooperation to carry out further studies.

\section{References}

Adams, M. Q. (2006). Nautical wine tourism: A strategic plan to create a nautical wine trail in the Finger Lakes wine tourism 
region of New York State, in J. Carlsen and S. Charters (Eds). Global wine tourism: Research, management and marketing. CAB International.

Alonso, A. D., (2005). Wine Tourism Experience in New Zealand: An Exploratory Study, PhD thesis, Lincoln University, Lincoln, NZ.

Arora, S. (2013). India's emerging wine industry. Wine Business International. Retrieved from http://www.wine-businessinternational.com/156-

bWVtb2lyX2lkPTQ4NiZtZW51ZV9jYXRfaWQ9Mw--enmagazine-magazine_detail.html

Boers, B., \& Cottrell, S. (2005). Sustainable tourism infrastructure planning: A GIS based approach. Retrieved from http://tm.dru.ac.th/003/text/boers341.pdf

Gammack, J. G. (2006). Wine tourism and sustainable development in regional Australia, in J. Carlsen and S. Charters (Eds). Global wine tourism: Research, management and marketing. $\mathrm{CAB}$ International.

Hande. (2013). Agricultural Officer, Grapes Division; Ministry of Agriculture, Pune, Maharashtra; Private Communication

Kirkman, A. (2010). The role of wine tourism in the marketing of wineries in the Stellenbosch wine route of South Africa. Masters' thesis submitted to University of South Africa. Retrieved from http://uir.unisa.ac.za/ bitstream/ handle/ 10500/4928/thesis_kirkman_a.pdf?sequence $=1$

Lone, P. A., Rather, N. A. \& Jain, S. (2013). An empirical analysis of tourist infrastructure quality in Jammu and Kashmir. Radix International Journal of Research in Social Science. 2(2). Retrieved from http://rierc.org/social/paper172.pdf

McNulty, P. (2011). Fundamentals \& principles of tourism product development. The 5th UNWTO/PATA Forum on Tourism Trends and Outlook, Guilin, China. Retrieved from http://dtxtq4w60xqpw.cloudfront.net/sites/all/files/pdf/pet er_mac_nulty_ fundamentals_and_principles_of_product_ development_0.pdf

Summary report on Infrastructure gaps in tourism sector at five tourist destinations in India based on perception of tourists. 
(2010). Ministry of Tourism (Market Research Division), Government of India. Retrieved from http://tourism.gov.in/ CMSPagePicture/file/marketresearch/studyreportsonevaluati on of planschemes $/ 01 \% 20$ Report $\% 20$ Vol-II.pdf

Ministry of Tourism Report (2009). Ontario Tourism Competitiveness Study. Ontario Tourism Infrastructure Research Study. Retrieved from http://www.mtc.gov.on.ca/ en/publications/Ontario_Tourism_Infrastructure.pdf

Roberts, L. \& Sparks, B. (2006). Enhancing the wine tourism experience: The customers' viewpoint. Global wine tourism: Research, management and marketing (eds J. Carlsen and S. Charters). CAB International.

Sharma, K. K. (2005). Tourism and development. Sarup \& Sons.

Sood D. \& Williams D. (2012) Wine Market Update 2012; USDA Foreign Agriculture Service; GAIN Report Number IN2162. Retrieved from http://gain.fas.usda.gov/ Recent\%20GAIN\%20Publications/Wine\%20Market \%20Update\%202012_New\%20Delhi_India_12-14-2012.pdf Study, Lincoln University, NZ.

Warnken, J. (2002). Tourist facilities and infrastructure audit. Retrieved from http://www.crctourism.com.au/wms/ upload/resources/bookshop/2-2_facilitiesaudit_v03_web.pdf 